DOI https://doi.org/10.30525/978-9934-588-81-5-2.27

\title{
INFLUENCE OF THE HERBAL MIXTURES \\ ON THE FUNCTIONAL STATE OF THE LIVER \\ IN DEXAMETHASONE-INDUCED INSULIN RESISTANT RATS
}

\author{
Savych A. O. \\ Candidate of Pharmacy (Ph.D.), \\ Assistant Professor at the Department of Pharnacognosy \\ with Medical Botany \\ Ivan Horbachevsky Ternopil National Medical University \\ of the Ministry of Health of Ukraine \\ Marchyshyn S. M. \\ Doctor of Pharmacy (Dr.habil.), Professor, \\ Head of the Department of Pharnacognosy with Medical Botany \\ Ivan Horbachevsky Ternopil National Medical University \\ of the Ministry of Health of Ukraine \\ Ternopil, Ukraine \\ Basaraba R. Yu. \\ Candidate of Pharmacy (Ph.D.), \\ Assistant Professor at the Department of Pharmacy \\ Higher State Educational Establishment of Ukraine \\ "Bukovinian State Medical University» \\ Chernivtsi, Ukraine
}

\begin{abstract}
Diabetes mellitus is one of WHO's priority issues. It requires immediate resolution as the epidemiological situation is gaining alarming proportions - the number of diabetic patients is increasing every year along with the number of deaths and disabilities due to the development of micro- and macro-angiopathies. According to the official information of International Diabetes Federation (2019), the number of patients is projected to increase to 642 million by 2040 [1].

An important problem of pharmacovigilance is that existing pharmacotherapy can effectively reduce hyperglycemia, but it is not always able to stabilize fluctuations in glycemic values during the day and maintain it at an optimal level. This leads to the development of the pathological processes cascade - excessive glycation and inactivation of the body's antioxidant defense system, triggering the processes of free radical oxidation of
\end{abstract}


lipids and, as a consequently, the formation of oxidative stress, which leads to the development and progression of diabetic angiopathies $[1,2]$.

Therefore, the optimization of pharmacotherapy, search and study of new drugs with hypoglycemic activity for the prevention and treatment of this disease and its dangerous complications is a top issue of pharmacy and medicine.

One of these areas is using herbal remedies, either as monotherapy for the prevention or in the mild stages of the disease or in the combination with traditional therapy in more severe forms of the disease. Phytotherapy is a justified method for the prevention and treatment because it has some advantages, such as relatively low toxicity, mild pharmacological effects and possibility to be used for long periods without significant side-effects, and it often well combines with synthetic drugs, has a complex activity through a number of biologically active compounds $[3,4]$. Particular attention deserve the combinations of different medicinal plants, because such herbal mixtures will have more biologically active substances that will influence on the all links of the pathogenetic mechanism of development of diabetes mellitus and its complications $[3,5]$.

Thus, the aim of our research was to study the influence of some herbal mixtures on the functional state of the liver in dexamethasone-induced insulin resistant rats.

The objects of study were the herbal antidiabetic mixtures No. 3 (Urtica dioica leaf, Cichorium intybus roots, Rosa majalis fruits, Elymus repens rhizome, Taraxacum officinale roots) No. 4 (Arctium lappa roots, Elymus repens rhizome, Zea mays columns with stigmas, Helichrysum arenarium flowers, Rosa majalis fruits), No. 7 (Inula helenium rhizome with roots, Helichrysum arenarium flowers, Zea mays columns with stigmas, Origanum vulgari herb, Rosa majalis fruits, Taraxacum officinale roots), No. 13 (Cichorium intybus roots, Elymus repens rhizome, Helichrysum arenarium flowers, Rosa majalis fruits, Zea mays columns with stigmas), No. 19 (Urtica dioica leaf, Taraxacum officinale roots, Vaccinium myrtillus leaf, Rosa majalis fruits, Mentha piperita herb), which are used in folk medicine for the treatment and prevention of diabetes mellitus type 2 [6]. It was used the herbal raw materials harvested in June - August 2019 in Ternopil region and Charpathians (Vaccinium myrtillus leaf) (Ukraine) during the study.

The samples of $10 \mathrm{~g}$ of each powdered herbal mixture were put into a $100 \mathrm{~mL}$ conical flask, was added $120 \mathrm{~mL}$ of distilled water to each. The aqueous extracts were obtained by heating in the boiling water bath for $30 \mathrm{~min}$. The extracts were filtered using Whatmann filter paper No. 1. Then the filtrates were evaporated by rotary evaporator and were lyophilized to 
dryness. The lyophilized powders of each herbal mixture were stored at $4{ }^{\circ} \mathrm{C}$ for further use.

The study was performed on male albino rats of the Wistar strain weighing between $180 \mathrm{~g}$ and $200 \mathrm{~g}$, which were bred at the animal house of the Central Research Laboratory of I.Horbachevsky Ternopil National Medical University, where they were kept under appropriate conditions (at a constant room temperature of $22 \pm 1^{\circ} \mathrm{C}, 40-70 \%$ humidity conditions and a 12-hour light/dark cycle). Throughout the experimental period, the animals received standard rat diet and water ad libitum. The animals were treated in accordance with the internationally accepted standard ethical guidelines for laboratory animal use and care as described in the European Community Guidelines [7].

Induction of insulin resistance by dexamethasone was performed according to the previously described protocol [8] with some modifications. Rats were randomly divided into eight groups of eight animals $(n=8)$ each and received different treatments once daily for 15 days. Group I (Control): received per os (p.o) distilled water $(12 \mathrm{~mL} / \mathrm{kg} /$ day) and intramuscular (i.m.) injection of $\mathrm{NaCl} 0.9 \%(1 \mathrm{~mL} / \mathrm{kg} /$ day). Group 2 (DEXA) received daily intramuscular injection of dexamethasone (KRKA, Slovenia) $(1 \mathrm{mg} / \mathrm{kg} / \mathrm{day})$ and distilled water $(12 \mathrm{~mL} / \mathrm{kg} /$ day, p.o.). Group III (DEXA+MET) received dexamethasone $(1 \mathrm{mg} / \mathrm{kg} / \mathrm{day}, \mathrm{i} . \mathrm{m}$.) and the standard drug - metformin (Lek S.A., Poland) (60 mg/kg/day, p.o.). Group IV-VIII (DEXA+EHM) received dexamethasone $(1 \mathrm{mg} / \mathrm{kg} / \mathrm{day}, \mathrm{i} . \mathrm{m}$.) and the aqueous extracts of the studied herbal mixtures $(12 \mathrm{~mL} / \mathrm{kg} / \mathrm{day}$, p.o. $)$. At the end of the experiment, rats were sacrifice by decapitation after anesthesia with Sodium thiopental (Abbott Park, IL, USA) and the blood was collected.

Determination of alanine aminotransferase (ALT) and aspartate aminotransferase (AST) activity was performed using commercial kits (FilisitDiagnostyka, Ukraine).

The values were expressed as mean \pm SEM. The data were analysed by using GraphPad Prism software version 5.03. The results were compared by using the ANOVA-One-Way test followed by Mann-Whitney $U$ test. The difference was considered statistically significant at $p<0.05$.

The administration of dexamethasone at a dose of $1 \mathrm{mg} / \mathrm{kg} /$ day for 15 days to linear rats caused the disorders of functional activity of the liver due to the increase of the activity of hepatic transaminases ALT and AST, which was $38 \%$ and $42 \%$ higher than in rats from the Control group. The administration of aqueous extracts of the herbal mixtures and metformin to dexamethasone-induced insulin resistant rats reduced ALT and AST activity almost to the values of the Control group. The extracts of the herbal 
mixtures No. 3 , No. 4, No. 7, No. 13 and No. 19 significantly reduced the ALT activity by $26 \%, 25 \%, 23 \%, 25 \%$ and $31 \%$, respectively, and AST activity by $42 \%, 35 \%, 38 \%, 42 \%$ and $42 \%$, respectively. The introduction of metformin showed similar results to the investigated herbal extracts, as the reduction in ALT and AST activity was $32 \%$ and $34 \%$ compared with DEXA group.

The results from the present study showed that aqueous extracts of the herbal mixtures No. 3, No. 4, No. 7, No. 13 and No. 19 possess potential hepatoprotective effect and reduce the disorders of functional activity of the liver, which was caused by dexamethasone administration.

\section{References:}

1. International Diabetes Federation / IDF Diabetes Atlas. 9th ed. Brussels, 2019. Available at: https://www.diabetesatlas.org

2. Differentiation of diabetes by pathophysiology, natural history, and prognosis / J. S. Skyler, G. L. Bakris, E. Bonifacio [et al.] // Diabetes. 2017. V. 66, № 2. P. 241-255.

3. The role of medicinal plants in the treatment of diabetes: a systematic review / W. Kooti, M. Farokhipour, Z. Asadzadeh [et al.] // Electronic physician. 2016. V. 8, № 1. P. 1832-1842.

4. Основні принципи використання лікарських рослин та їх зборів для ліування та профілактики цукрового діабету 2 типу (Огляд літератури) / А. О. Савич, С. М. Марчишин, Г. Р Козяр, О. Я. Скринчук // Фітотерапія часопис. 2019. № 4. С. 43-46.

5. Antihyperglycemic, hypolipidemic and antioxidant properties of the herbal mixtures in dexamethasone-induced insulin resistant rats / A. Savych, M. Marchyshyn, R. Basaraba, M. Lukanyuk // Pharmacologyonline. 2020. № 2. P. 73-82.

6. Товстуха С. С. Золоті рецепти української народної медицини / Є. С. Товстуха. К.: Краӥна мрій, 2010. 550 с.

7. EEC «Council directive 2010/63/EU, of the 22nd September 2010 on the approximation of laws, regulations and administrative provisions of the member states regarding the protection of animals used for experimental and other scientific purposes» / Offical Journal of the European Communities. 2010. P. 1-29.

8. Доклінічні дослідження лікарських засобів: методичні рекомендації / за ред.: член-кор. АМН України О. В. Стефанова. К. : Авіченна. 2001. 528 с. 